\title{
The Prison Industrial Complex: The Final Solution to the Three-fifths Problem Mujahid Farid
}

The whole law and order movement that we have heard so much about is

- in operation - anti-black and anti-underclass. Not in plan, not in design, not in intent, but in operation.

- Professor Norval Morris, former Dean of the University of Chicago Law School.

History has a tendency of repeating itself. Oftentimes the repetitious cycle comes in a different format but the broader dynamics are the same. Then it may require astuteness to recognize the path well-travelled. I find this to be the case with the thoroughly entrenched Prison-Industrial Complex (PIC) (Davis, 2003). It is my contention as others have argued (e.g. Davis and Mendieta, 2005), and I hope to show, that the prison experiment in the West is inextricably rooted in the chattel slave system, but has been masked so well in the culture of crime that even many well-meaning prison abolitionists could miss the full import of this insidious connection.

To make this point I focus on New York prisons for several reasons: I have been a continuous New York State prisoner for what is now approaching thirty-three years; New York is a state which has openly used prison expansion as a tool for addressing a wide range of social problems; its prison system seems to reflect a wider penal philosophy in America and growing worldwide; and New York prisoners have a rich history of literary analyses and protest to which I have often contributed.

The term PIC has an interesting historical connection and the word complex itself has at least two meanings that make it an appropriate double entendre. One definition is: "consisting of inter-connected or interwoven parts," and consequently hard to understand fully. In the realm of psychology the meaning of complex is an "exaggerated or obsessive concern or fear" (American Heritage, 2004). The current colloquial terminology dates back about fifty years.

Shortly before leaving office in the early 1960s, President Dwight D. Eisenhower made an announcement that was somewhat unexpected from someone with a long military career and his credentials. He warned the American public about a growing social phenomenon and the warning rang so true that the phrase he coined describing it entered the argot. The 
phrase, now common in social and political studies, is "Military-Industrial Complex" (MIC). Eisenhower had grown concerned about a threat to American democracy when fears of a missile gap with the Soviet Union were promoted by a cabal of power elites. Eisenhower noted that a close relationship amongst military, political, business, and media elements had coalesced to assist each other in perpetuating selfish economic and pecuniary interests. This movement was built on the type of capitalist jingoism reflected in G.M. President Charles Wilson's earlier statement that "What is good for the country is good for General Motors, and vice versa".

Here, we find earlier expressions of the current day too-big-to-fail policy where the government comes to the rescue in big business fiascos notwithstanding evidence of sordid and even criminal practices. While comparing the prosecution and subsequent imprisonment of Bernard Madoff for his infamous financial breach-of-trust with other governmental activity, one social analyst asked: "On the larger canvas, what exactly separates Madoff's operation from those of the banks rewarded for their shady follies by a $\$ 700$ billion bailout? [...] the banks finally had to admit that all of their public financial statements were false [...] unlike Madoff who looted his clients of a mere $\$ 50$ billion, they were 'too big to fail"' (Cockburn, 2009). Thus, we also see in the historical MIC the makings of big business interests being the driving force of government policy, even when those policies benefit a few at the expense of the masses.

Capitalist expansion - especially to the benefit of the propertied class - relies on schisms and tricks to hoodwink the masses, and success usually requires a scapegoat. To establish the MIC communists were the designated boogeyman. Once the American public was primed with the fear of communist hegemony - the Red Scare - they were ready for milking. As the perceived threat of Red domination loomed over the heads of the masses like the mythological Sword of Damocles, the real threat to the American economy and pocketbook of common people came from within a classic sleight-of-hand technique. The practical effect of the MIC was the American public finding itself financing the enrichment of an elite business cabal associated with the Defence Industry. During the presidency of Ronald Reagan a substantial portion of the nation's budget was spent on the "Star Wars" program even while funding for social services for the underclasses was consistently cut back. The insatiable beast was unleashed and sucking the economic lifeblood of a sleeping and deluded public. 
Over time a new existential reality developed in the United States. With the fall of the Soviet Union and the development of a new global economic order, the MIC was threatened with serious downsizing, if not obsolescence. As capitalist expansion crept towards its zenith the name of the game changed. The power elite in America then promoted the North Atlantic Free Trade Agreement ("NAFTA") and subsequently the General Agreement on Tariffs and Trade ("GATT"). These governmental enactments gave the business class the incentive to re-locate their productive capabilities and factories overseas to countries where they could cut costs by employing cheap labour. What also emerged from this new reality was a shuffling of the power elite domestically. With the loss of manufacturing, more and more, the business sector of the power elite became dominated by those who wielded influence in the financial markets and Wall Street. In 2006, the average CEO was paid 364 times what the average worker earned, up from 42 times more in 1980 - the world's largest income gap between classes (Prins, 2009). The insatiable beast had become leviathan. This new reality called for domestic re-direction, updating the sales-pitch, and finding an appropriate scapegoat.

From the perspective of the power elite it was the PIC that could address some aspects of the evolving social and economic reality. The social planners recognized in the PIC the opportunity to kill two birds with one stone by appeasing their mainly white rural constituents who had been economically and structurally displaced by the emerging global dynamics, and at the same time deal with the perennial problem of Blacks in the midst - people never accepted as full-fledged Americans and whose historical usefulness as chattel had become obsolete. Since 1980, government spending on prison building has been a Bull Market on Wall Street with investors finding a host of ways to tap into this developing phenomenon as if it was the new "gold rush" (Christie, 2000). The PIC includes some of the nations largest architecture and construction firms, plumbing supply companies, healthcare companies, food-service providers, security providers, and much more (Schlosser, 1998). Now private-run prisons have become the fastestgrowing segment of the PIC (ibid, p. 64).

In speaking of the PIC, let us first recognize that similarly as the MIC, this is largely an American phenomenon with the United States being the world's largest prison camp, beating out every other nation, even communist China with its over one billion people (Schlosser, 1998, p. 52). In 2002, 
in preparation for his State of the Union Address, President George W. Bush had his speechwriting team come up with a phrase he could use to effectively manipulate the public to support his desire to invade Iraq. The sinister phrase developed by the team was "axis of evil", a theologically loaded term that associated Iraq with North Korea and Iran (Bumiller, 2007, pp. 173-175). It is indeed ironic that the United States imprisons more of its population than the so-called axis of evil, and George W. Bush never spoke out against the prison-building frenzy at home; nay, he found nothing evil about it and was part of the process.

While undoubtedly the entrenchment of prisons in the United States is attributed to class and economic conflict, race plays a significant role in this policy choice and is sometimes, wittingly or not, downplayed or overlooked. In the United States African Americans have never, by and large, been accorded full citizen status by the power elite. It is well-known that the U.S. Constitution designated Black Americans to be counted only as three-fifths of a person (Davis, 2003). Some believe this assignment was abrogated with the passage of the thirteenth and fourteenth amendments to the Constitution, but the situation both de jure and de facto belies that conclusion. It appears that the assignation of lower status to Blacks was never intended to be fully abridged. Contrary to popular belief, the thirteenth amendment did not abolish slavery in the United States. What it did was abolish slavery except in instances where a person had been duly convicted of a crime. Thus, the Peculiar Institution remained intact so long as it was supported by the stigma of criminal conviction.

Many social scientists appeared shocked and dismayed when classic research studies in the 1990s revealed that one of every four American males in his 20s was under the control of the criminal justice system (Mauer, 1999). By 1996 in New York State that number had elevated to one in three (Butterfield, 1996). Beginning in the 1980s, a supposedly liberal governor in New York, Mario Cuomo, added more prison beds than all previous governors in the state's history combined (Schlossler, 1998). The crux of the new prisons built in New York to accommodate the influx of bodies were constructed in an area called the "North Country" (ibid, p. 57; see also Ransome, this volume). The North Country is six contiguous counties in the upstate Adirondack region reaching from Lake George to the Canadian border. The population of the North Country is almost exclusively white, politically conservative, and save for the prisons, economically depressed. 
As the MIC took shape President Eisenhower knew there was no missile gap, and just as the MIC proponents conjured an unreasonable heightened fear of communists, so too did the PIC proponents with crime as the central issue and prisons as the panacea. It was understood that success of the imprisonment program required a boogeyman; a tangible and identifiable group to provide fodder for the juggernaut. In America there was a ready clientele waiting.

During a period of research, prisoners at the Green Haven Prison in New York looked at the anecdotal disproportionate incarceration of minorities and discovered that 85 percent of the prison system was African American or Latino, and 75 percent of minority prisoners come from only seven neighbourhoods in New York City to which 95 percent of them return upon release. Most of the remaining 25 percent of prisoners come from the other five major urban communities throughout the state (Green, 1994, p. 20). Since African Americans comprised only 17 percent of the state's population, this statistical anomaly cried out for further investigation and explanation.

Some social analysts think that it is wrong to view the racial configuration of the prison population vis-à-vis its employees as deliberate and planned. Their position is that this situation is the result of unintended consequences. For example, Professor Morris, whom I quote in the opening of this paper, takes the position that the "anti black" component of the PIC is only so in "operation $[. .$.$] not in intent". I challenge this statement and cannot imagine$ a similar socio-economic arrangement, in America, where the racial component is so reversed. It would seem that from this reversal standpoint the notion of explaining the situation as unintentional becomes untenable. Yet, even Loic Wacquant, in his seminal work connecting slavery to the prison system seems to vacillate on the motivating factor of race where he states: "An unforeseen by-product of the systematic enslavement and dehumanization of Africans and their descendants on North American soil was the creation of a racial caste line separating what would later become labelled 'blacks' and 'whites"'. (Wacquant, 2002, p. 45, original emphasis). It appears that, to many researchers, a finding of racial motivations primordial over the economics is simply too much to grapple with.

In any event, an interesting phenomenon that occurred during the height of prison expansion in New York, and which may be racially motivated or be rooted in the desire to maintain the chattel slave mentality, was the outcry 
from a segment of the public, encouraged and led principally by prison guards and employees, to deprive and take back any service or amenity afforded to prisoners and deemed to be a perk. In a full-page advertisement taken out by the prison guard union in the Middletown Sunday Record in 1991, the guards launched an attack against prisoners receiving free medical and dental care; commissary discounts; five free letters per week; getting paid for work; provision of AIDS treatment; free G.E.D. testing; parole for long-termers; and especially providing college education to prisoners.

With the support of their legislative representatives, power elites and media outlets, the prison guards prevailed in having most of these so-called perks rescinded. Many of these policy changes were obviously irrational. For example, it is widely recognized that prison recidivism and level of education are inversely related. Yet, the college programs were yanked based on the seemingly racial angst of providing higher education to a largely Black population. In addition, providing prisoners with the five free letters was predicated on the long-established fact that a prisoner who maintains family ties and community connections is also less likely to recidivate. Nevertheless, the free letters were yanked. Perhaps the objective was to appease rural constituents' visceral hatred, even though it ran counter to rehabilitation or just maybe Black recidivism was precisely the objective in the grand scheme.

Concomitant with the assault against providing higher education and other so-called perks to prisoners, prison staff and administrators commenced a movement to keep prisoners docile and accommodationist - a return to the days of yore. We witnessed all the originally prisoner-inspired, created and directed progressive programs that came into being after the Attica rebellion of 1971 be co-opted by prison staff. These programs no longer focused on prisoner empowerment, but instead they morphed into vehicles primarily for jobs for white rural residents. For example, the acclaimed "Pre-release Centers", which had long assisted prisoners in developing job skills and community connections while confined and also facilitates release were disbanded. In their place came "Transitional Services", a program sponsored by the prison system and controlled by counselling staff. Likewise, Alcohol Anonymous (A.A.), Narcotics Anonymous (N.A.), Alternatives to Violence (A.V.P.), and other therapeutic programs, all of which had been run by prisoners and civilian community volunteers, were made dysfunctional and replaced by the counselling staff with "ASAT", "ART" and the "PHASE I, 
II, \& III" programs. What essentially happened was the curricula stayed the same, but the name changed and the new instruction taken over by prison staff. And of course the new programs became mandatory. The practical effect - more jobs.

Individual expression by prisoners began to be suppressed with jailhouse lawyers becoming a prey more hunted and scorned by prisoner administrators than violent predators. The idea was to limit judicial oversight over the new direction. Suddenly prisoners found legislative changes making it more difficult to bring a civil case in court. In 1999, the New York State statute that regulates "poor person" civil filings in the courts was amended to specifically affect prisoners. The New Amendment states: "If the court determines that the inmate has insufficient means to pay the full filing fee, the court may permit the inmate to pay a reduced filing fee, the minimum of which shall not be less than fifteen dollars and the maximum of which shall not be more than fifty dollars" (see New York C.P.L.R.1101(f)(2)). This means that even after the prisoner proves that he is poor and cannot afford to pay, he still must pay between fifteen and fifty dollars. This rule only applies to prisoners and a poor person in society would not be subjected to the reduced fee.

The change to the poor person statute in the Federal system is more onerous. This change made in 1995 reads: "Notwithstanding subsection (a), if a prisoner brings a civil action or files an appeal in forma pauperis, the prisoner shall be required to pay the full amount of a filing fee". The section under 28 U.S.C.A. 1915 allows the prisoner to pay the filing fee in instalments - but every penny of it must be paid. Currently, the filing fee for a civil action in the Federal system is $\$ 350$. If the prisoner chooses to appeal an adverse decision it's another $\$ 455.00$.

With all of these onslaughts, the animosity and contempt directed towards prisoners by prison staffers reached a pitched level and nothing could compare to the situation in the North Country with prisoners confined there finding themselves subjected to daily brutality - often without even committing any rule infraction. In the North Country prisoners are not allowed to forget how thoroughly despised they are by the prison staff. One may wonder, beyond the question of race, why the unnecessary rage? Actually, the answer may lie beyond race since in the North Country this rage is directed at Black and White prisoners alike. It can be explained by a well-recognized socio-psychological phenomenon. It may be that this 
inordinate severe treatment is explained by "cognitive dissonance". That is, many residents of the North Country - whose very livelihood depends on the prison economy - who are on the one hand being upstanding and noble people, and on the other hand being parasites dependent on human misery, must convince themselves that the prisoners under their charge are all inherently deficient, even evil, and therefore not deserving of basic humane treatment. Thus, they themselves are not parasites; the economic relationship is preordained by Providence.

During the rise of the PIC the blame-the-victim mindset and justification for social policy received some support from elements of academia. In 1965, in a startling report, Daniel Patrick Moynihan introduced the idea of a "culture of poverty" wherein he posited that the black urban family was caught in an inescapable tangle of pathology. While Moynihan's analysis never lost its appeal in certain conservative quarters, for quite some time it was taboo in academia to conduct research or offer policy recommendations based upon its premises. However, the Moynihan analysis had a resurgence and measure of success when President Bill Clinton signed a bill in 1996 "ending welfare as we know it" (Cohen, 2010). Clinton's initiative prevailed largely on arguments that the welfare system, with its large percentage of unmarried black mothers, was contributing to self-perpetuating moral deficiencies (ibid). Cohen (2010) notes that at a recent annual meeting of the American Sociological Association, the attendees discussed the resurgence of scholarship on culture and poverty. One very prominent attendee was quoted as saying: "We've finally reached the stage where people aren't afraid of being politically incorrect", and that "Moynihan was unfairly maligned" (ibid). This issue of cognitive dissonance has come more to the forefront with a newly developing political and economic scene nationally and especially in New York State. In the quest to expand the PIC, or to even maintain the status, the veneer of crime has been lost.

Throughout the past decade or so, the PIC proponents and its benefactors began confronting a serious dilemma. That is, the crime rate began dropping drastically, not only in New York State but throughout the country. Facing this kind of change made it difficult justifying the cry for an ever-expanding PIC (New York Times, 2011). Yet, despite that difficulty, PIC proponents have somehow fought an uphill battle to keep the money flowing and have thus far survived rational business practices. David Paterson's budget during his waning days in the governor's office 
notes that the prison population in New York dropped from a peak of about 71,600 in 1999 to about 56,000 in 2010. Nevertheless, the state prison budget rose from 2.3 billion in 2000 to 2.8 billion today (ibid). Similarly, the governor in Nevada wanted to close the 148-year-old Nevada State Prison in Carson City after a business advisory group said it was economically unsound to keep it open. The opinion was supported by the prisons' commissioner. It was established that the prison required three times as many guards per prisoners as a modern prison - which Nevada had already built. The prison guards union opposed the closing, citing the jobs that would be lost, and the prison escaped the legislative axe (Cauchon, 2010). A confluence of developments in New York, however, have compelled government representatives and officials to face the PIC once and for all. The PIC's days of reckoning may finally have arrived.

With the ever-decreasing crime-rate, change of the legislative guard, and a critical international economic crisis, eventually the closing of prisons became something not just timidly discussed, but actualized. Before completing his term in office, Governor Paterson mustered the courage to actually close a few prisons, though nowhere on the scale that he had originally proposed as he closed mostly a few small "satellite" facilities. Even so, the North Country politicians read the handwriting on the walls and went into an uproar. Responding to Paterson's milquetoast downsizing, one state senator representing the North Country is quoted as saying: "It's unfair [...] our area responded with open arms when the state began looking for locations for prisons over two decades ago [...] today, the prison closings are killing our economy" (Reagan, 2010). ANorth Country Chamber of Commerce executive director declared: "Gov. David A. Paterson is recommending cutting costs and saving money by shutting down the Ogdensburg Correctional Facility. This proposal is a disaster for St. Lawrence County and must be stopped. If it succeeds, more than 287 professionals will be out of jobs" (Id.). Now, the masks, pretensions and illusions are gone. The arguments for supporting the $\mathrm{PIC}$ is no longer crime reduction - it is openly an issue of jobs. The position of the PIC proponents is clear: "Crime reduction be damned. Go find or make black bodies to keep our economy alive!"

That cry may now be hollow - sterilized by the test of time. It appears that the confrontation against PIC expansion has even been ratcheted-up, at least by a few degrees. When the incoming governor assumed office in January 2011, one of the first items he mentioned for his tentative budget 
balancing was the shutting down of prisons (New York Times, 2011). Although stranger things may have happened before, the newly installed governor, Andrew M. Cuomo, is the son of the former governor Mario Cuomo - the same Mario Cuomo who singularly led the largest prison expansion in the state's history.

When Andrew Cuomo gave his State of the State Address on 5 January 2011 he employed unusually strong language to attack the PIC and its modus operandi. Amongst other things, he stated: "An incarceration program is not an employment program. If people need jobs, let's get people jobs. Don't put other people in prison to give some people jobs [...] That's not what this state is all about and that has to end this session" (Murtaugh-Monks, 2011). Citing Andrew Cuomo's visits to Sing-Sing, Manhattan Psychiatry Centre and Tyron Juvenile Residential Facility just "days" after his election, some PIC opponents believe that there is reason to believe the tide is turning (ibid). This father-son diametric approach may be explained by the father's embarrassment - after his three terms in office - of his prison legacy to New Yorkers (Schlosser, 1998, p. 57). The father referred to it as "stupid, an immoral waste of scarce state monies, an obligation forced on him" (ibid). So, it might be understandable that the son would feel a personal responsibility to work at cleaning up the mess.

What could facilitate the downfall of the PIC is a political development that goes to the very root of formulating the three-fifths doctrine. Snce the adaptation of the North Country as a PIC region, the North Country, in violation of the State Constitution, counted prisoners as residents of the North Country for the purposes of the census. The practice gave inflated political power to upstate communities where most prisons are located, by allocating more residents to those communities than would be merited if prison populations were not counted. This allowed additional legislators to be assigned to those communities while diminishing the number of legislators assigned from which the majority of prisoners derived. New York's prisoners are not allowed to vote, but their presence in upstate prisons, where their vital interests often run opposite to the white rural residents, gave the PIC proponents in those communities the political clout required to perpetuate the relationship. The more prisons that were established in the North Country, the more difficult it became to challenge the practice.

Prior to leaving office, Governor Paterson signed legislation ending the longstanding practice of counting prisoners in the prisons where they 
are confined. In New York State prison-based gerrymandering has ended (New York Times, 2010). Although the practice has ended in New York, it is still rampant in states throughout the country. For example, in Virginia as a result of the U.S. Census Bureau counting prisoners in the countries where they are confined, "every single resident of districts 1, 2, 3, and 4 in Powhatan County is padded with prisoners" (Green, 2010). There is one county in Virginia, Southampton, where prisoners constitute 58 percent of the population (ibid). This reliance for political power on disenfranchised prisoners, whom the benefactors supposedly despise and regularly abuse, is all too reminiscent of the three-fifths compromise included in the United States Constitution.

The New York change ending the practice could have a significant effect on the state's political map. Seven upstate Senate districts could have trouble meeting the federal population requirements - meaning those districts will cease to exist (New York Times, 2010). Does this definitively mean that the PIC is about to be crushed? Perhaps and perhaps not. We do know that the power, influence, and vested interests in the PIC are not to be taken lightly and no one or few politicians will likely have the wherewithal to cause it lasting harm. But even if it is crushed, the point I make here is "so what?" We should bear in mind that the PIC demise does not necessarily spell the demise of slavery. One astute researcher has identified four "peculiar institutions" that have successively operated to define, confine, and control African Americans in the history of the United Stated. They being (a) chattel slavery; (b) the Jim Crow system; (c) the Ghetto; and (d) Prisons (Wacquant, 2002). The resurrection and rise of the phoenix can come in myriad forms.

Hopefully, the foregoing explains my view that, in the American context, that abolitionists who concentrate their focus on prisons, per se, may lose sight of the magnitude of the problem. The struggle to maintain racial inequality in America has and can morph into forms that may be immediately out-of-sight.

I have a dream. I dream to be free; not just from the clutches of the PIC, but free from American slavocracy - in whatever form it may be.

\section{REFERENCES}

American Heritage (2004) American Heritage College Dictionary, Boston: Houghton Mifflin Company. 
Bumiller, Elisabeth (2007) Condoleezza Rice: An American Life, New York: Random House.

Butterfield, Fox (1996) "Study Finds a Disparity in Justice for Blacks", New York Times - February 13.

Cauchon, Dennis (2010) "Unneeded prison eludes budget axe", USA Today-March 15.

Christie, Nils (2000) Crime Control as Industry: Towards Gulags, Western Style (third edition), London: Routledge.

Cockburn, Alexander (2009) "A Giant Ponzi Scheme", The Nation - January 5.

Cohen, Patricia (2010) “"Culture of Poverty', Long an Academic Slur, Makes a Comeback", New York Times - October 18.

Davis, Angela Y. (2003) Are Prisons Obsolete?, New York: Seven Stories Press.

Davis, Angela Y. and Edward Mendieta (2005) Abolition Democracy: Beyond Empire, Prisons, and Torture - Interviews with Angela Y. Davis, New York: Seven Stories Press.

Green, Alice P. (1994) "Black Prisoners Organize for Self-Empowerment”, The National Prison Project Journal, 9(1): 1, 2, 20.

Green, Frank (2010) "Prison populations distort districting", Richmond Times-Dispatch - September 5.

Mauer, Marc (1999) Race to Incarcerate, New York: The New Press.

Murtagh-Monks, Karen (2011) “A Message From the Executive Director", Pro Se, 20(6): 2.

New York Times (2011) "Expensive Prisons", New York Times - February 8.

New York Times (2010) “An End to Prison Gerrymandering”, New York Times - August 23.

Prins, Nomi (2001) "Throwing Good Money...", The Nation - January 5.

Reagan, Jim (2010) "Prison Critics Want 12 Closed", Advance News - February 14.

Schlosser, Eric (1998) "The Prison-Industrial Complex", The Atlantic Monthly, December: 51-77.

Wacquant, Loïc (2001) "From Slavery To Mass Incarceration", New Left Review, 13: 41-60.

\section{ABOUT THE AUTHOR}

Mujahid Farid has been a prisoner in New York State for the past thirtythree years. He is serving a sentence of fifteen years to life for a conviction of attempted murder of a New York City policeman after being accused of trying to fire a pistol, which misfired, at the plainclothed officer. He has been denied parole nine times, every two years, since 1993, and maintains his innocence. He states that in New York parole denials are being widely applied to long-term prisoners and is part and parcel of the PIC movement and its supporters in the penal system. He is one of the founding members of the widely acclaimed PACE (Prisoner for AIDS Coounseling \& Education) program in the New York prison system. In 1990, he won the PEN American 
Center's first prize award in non-fiction for his account on the struggle for AIDS education in prison. Mujahid can be reached at either of the following addresses:

\section{Mujahid Farid}

\#79A0362

Franklin Correctional Facility

62 Bare Hill Road - P.O. Box 10

Malone, New York 12953

USA

Mujahid Farid

2917 Parkwood Avenue

Richmond, VA 23221

USA 